\title{
Ratio legis minimum percentage of share ownership of the limited company in the perspective of justice
}

\author{
Ratio legis percentual mínimo de participação acionária da sociedade limitada na perspectiva da \\ justiça \\ Ratio legis porcentaje mínimo de participación accionaria de la sociedad limitada en la perspectiva \\ de la justicia
}

Received: 01/12/2021 | Reviewed: 01/12/2021 | Accept: 01/17/2021 | Published: 01/21/2021

Adi Widjaja

ORCID: https://orcid.org/0000-0002-3250-7469 Universitas Brawijaya, Indonesia E-mail: adiwidjaja74@yahoo.com

Abdul Rachmad Budiono

ORCID: https://orcid.org/0000-0001-6010-6470 Universitas Brawijaya, Indonesia

E-mail: Abdulrachmadbudiono@gmail.com

Sihabudin

ORCID: https://orcid.org/0000-0002-9746-0913 Universitas Brawijaya, Indonesia E-mail:sihab@ub.ac.id

Siti Hamidah

ORCID: https://orcid.org/0000-0001-6805-5217 Universitas Brawijaya, Indonesia E-mail: hamidah@ub.ac.id

\begin{abstract}
This study aims to determine and analyze the ratio legis to determine the minimum percentage of $10 \%$ minority shareholding in Law Number 40 of 2007 concerning Limited Company. The methodology used in this research is normative legal research with a statute approach and a conceptual approach. The results showed that the ratio legis for determining the minimum percentage of minority share ownership of 10\% in Law Number 40 of 2007 concerning Limited Company consists of four things, namely the condition of the Indonesian economy when Law Number 40 of 2007 was made, also influenced the determination the minimum percentage number for minority shareholding, so that in Indonesia the number $10 \%$ is determined, the $10 \%$ percentage number is not the majority number, the $10 \%$ number is a reasonable percentage number for shareholders who have paid up capital to be considered as minority shareholders, and the $10 \%$ number is determined. carried out by considering the value of the rupiah that has been deposited by the shareholders as paid up capital.
\end{abstract}

Keywords: Ratio legis; Minimum percentage; Minority share ownership; Limited company.

\section{Resumo}

O presente estudo tem como objetivo determinar e analisar a ratio legis para determinar o percentual mínimo de $10 \%$ de participação minoritária na Lei n ${ }^{\circ} 40$ de 2007 relativa à Sociedade Limitada. A metodologia utilizada nesta pesquisa é a pesquisa jurídica normativa com uma abordagem de estatuto e uma abordagem conceitual. Os resultados mostraram que o rácio legis para determinar a percentagem mínima de participação minoritária de $10 \%$ na Lei n. ${ }^{\circ} 40$ de 2007 relativa às sociedades anónimas consiste em quatro coisas, nomeadamente a condição da economia indonésia quando a Lei n. ${ }^{\circ} 40$ de 2007 foi feita, também influenciou a determinação do número percentual mínimo de participação minoritária, de modo que na Indonésia o número $10 \%$ é determinado, o número percentual de $10 \%$ não é o número da maioria, o número de $10 \%$ é um número percentual razoável para acionistas que integralizaram capital para ser considerados acionistas minoritários, sendo fixada porcentagem de $10 \%$. realizado considerando o valor da rúpia que foi depositado pelos acionistas como capital integralizado.

Palavras-chave: Razão legislativa; Porcentagem mínima; Participação minoritária; Sociedade limitada.

\section{Resumen}

Este estudio tiene como objetivo determinar y analizar el ratio legis para determinar el porcentaje mínimo de participación minoritaria del 10\% en la Ley Número 40 de 2007 de Sociedad Anónima. La metodología utilizada en esta investigación es la investigación jurídica normativa con enfoque de estatuto y enfoque conceptual. Los resultados mostraron que el ratio legis para determinar el porcentaje mínimo de participación minoritaria del $10 \%$ en la Ley 
Número 40 de 2007 sobre Sociedades Anónimas consta de cuatro cosas, a saber, la condición de la economía indonesia cuando se promulgó la Ley Número 40 de 2007, también influyó en la determinación del número de porcentaje mínimo para la participación minoritaria, de modo que en Indonesia se determina el número del 10\%, el número de porcentaje del 10\% no es el número mayoritario, el número del 10\% es un número de porcentaje razonable para los accionistas que han desembolsado capital a ser considerados accionistas minoritarios y se determina el 10\%. realizado considerando el valor de la rupia que ha sido depositada por los accionistas como capital desembolsado.

Palabras clave: Ratio legis; Porcentaje mínimo; Participación minoritária; Sociedad anónima.

\section{Introduction}

After Law Number 1 of 1995 is valid for approximately 12 (twelve) years, along with the changes that occur and develop in the business world, the presence of Law Number 1 of 1995 is felt to no longer be able to accommodate the various changes that have occurred in business activities. Law Number 1 of 1995 is felt that it is no longer fully able to provide maximum service to business actors in carrying out their activities. Subsequent developments, it turned out that the provisions in Law Number 1 of 1995 was seen as no longer able to meet legal developments and the needs of society, so a new law was made, namely Law Number 40 of 2007 concerning Limited Company.

In terms of obligations, it is the obligation of the shareholders to deposit the company's capital in accordance with the Company's Articles of Association. When it is related to the rights of shareholders, what needs to be paid attention is the rights of minority shareholders, which are in the articles of Law Number 40 of 2007 concerning Limited Company has determined or determined the minimum percentage limit for minority shareholding is $10 \%$.

Minority shareholders are one of or more shareholders or groups of shareholders who have a small share of shares in a Limited Company, so that minority shareholders have limitations in exercising their rights as shareholders, and minority shareholders are unable or unable control the management of a Limited Company, or do not have a decisive position in terms of selecting the management of a limited company.

Justice and legal protection for minority shareholders that have been implemented, generally provide a number of rights and obligations for shareholders guaranteed by law. However, the provisions in Law Number 40 of 2007 concerning Limited Company are not sufficient to provide justice and legal protection for the interests of minority shareholders. Besides that, the condition of minority shareholders who are generally weak, and the attitude of majority shareholders, Directors and Commissioners who are not moral (moral hazard) in managing a Limited Company and do not have good intentions in making decisions at the General Meeting of Shareholders (GMS) or the Extraordinary General Meeting of Shareholders (EGMS). What is meant by the condition of weak minority shareholders is that minority shareholders often lose their votes in decision making at the GMS or EGMS, plus the condition that often occurs is that minority shareholders do not become company managers, so they do not know the real conditions in the company.

One issue that needs attention is the ratio legis for determining the percentage of minority shareholders is $10 \%$, because this is related to the interests of shareholders in obtaining justice and legal protection for minority shareholders. With the position as a minority shareholder, justice and legal protection for minority shareholders are important, for this reason the ratio legis for determining the percentage of minority shares is $10 \%$ in Law Number 40 of 2007 concerning Limited Company which is the subject of discussion very important.

Law Number 40 of 2007 has determined that minority share ownership is 10\%, this can be seen from the Articles in Law Number 40 of 2007, namely in Article 79 paragraph (2), Article 97 paragraph (6 ), Article 114 paragraph (6), Article 138 paragraph (3), and Article 144. Based on Law Number 40 of 2007 concerning Limited Company, Article 79 paragraph (2), Article 97 paragraph (6), Article 114 (6), Article 138 paragraph (3), and Article 144, the contents of these articles contain the words that explicitly state "1/10 (one tenth) or more of the total shares with voting rights". From the mention of the number $1 / 10$, it can be explained that Law Number 40 of 2007 does not explicitly stipulate a minimum percentage limit for minority share 
ownership is $10 \%$ (ten percent), but it can be understood that in Law Number 40 of 2007 applies the minimum percentage limit of minority share ownership is $10 \%$ (ten percent).

There are articles in Law Number 40 of 2007 in which there are no words that clearly state "1/10 (one tenth) or more of the total shares with voting rights", namely Article 79 paragraph (6) and Article 80 paragraph (1) Law Number 40 of 2007. From the contents of these Articles, it shows that Article 79 paragraph (6) and Article 80 paragraph (1) of Law Number 40 of 2007 are directly related to the minimum ownership proportion limit of $10 \%$ minority shares, so that minority shareholders with a proportion of share ownership below 10\% cannot use their rights are based on Article 79 paragraph (6) and Article 80 paragraph (1) Law Number 40 of 2007.

General legal protection for every shareholder is contained in Article 61 paragraph (1) Law Number 40 of 2007, which reads:

Each shareholder has the right to file a lawsuit against the Company to the district court if they are harmed due to the Company's actions which are considered unfair and without reasonable reasons as a result of the resolutions of the GMS, Directors and / or the Board of Commissioners.

Article 61 shows that Law Number 40 of 2007 provides legal protection for every shareholder, to file a lawsuit regardless of the percentage of share ownership he owns. Thus, shareholders who own shares, even though they are small, for example $0.5 \%$ or $1 \%$ or more, either less than $10 \%$ or more than $10 \%$, have the right to use this Article 61 in filing a lawsuit in the District Court.

The relationship between the protection of minority shareholders and the principle of justice is also reflected in the provisions of Article 61 of Law Number 40 of 2007 which give minority shareholders the right to sue companies that have committed unfair acts against minority shareholders (Kadir, 2017).

Thus based on Law Number 40 of 2007, the minimum percentage of minority shareholding is $10 \%$, so that the understanding of minority shareholders in this study is 1 (one) or more shareholders who have a small share of shares in a Limited Company, with a total percentage. share ownership of less than $10 \%$ (below ten percent).

Thus in Law Number 40 of 2007, there are already articles that aim to provide rights to shareholders with the aim of providing justice and legal protection for shareholders, however, these articles require a $10 \%$ share ownership percentage before the shareholders can use all of them. these articles are to protect their rights as shareholders.

If the percentage of share ownership is less than $10 \%$, some of the rights of the shareholders are lost, so that the shareholders can only get justice and legal protection through Article 61 of Law Number 40 of 2007. This situation shows that based on Law Number 40 of 2007 concerning Limited Company, the minority shareholders have not received justice and legal protection.

In fact, according to Gustav Radbruch, there are three basic values of law, namely: Justice, Usefulness and Benefit of the law. People not only need regulations that guarantee legal certainty in their relationship with each other, but also need justice besides the law to serve their interests (Prasetyo \& Barkatullah, 2014). According to Radbruch, the value of justice is the crown of every legal system. The value of justice is "material" which must be the content of the rule of law, while the rule of law is "form" which must protect the value of justice (Tanya, et.al, 2013).

Based on the aforementioned background, it shows that determining the minimum percentage of minority shareholding in Law Number 40 of 2007 concerning Limited Company of 10\% is very important. Therefore, in this article, we will discuss the issue of ratio legis determining the minimum percentage of $10 \%$ minority share ownership in Law Number 40 of 2007 concerning Limited Company. 


\section{Methodology}

The method used in this research is normative legal research. In normative legal research, there is no need to support data or social facts (Nasution, 2008).

The materials used in this research are primary legal materials in the form of statutory regulations, and secondary legal materials in the form of legal literature that are relevant to the issues discussed (Marzuki, 2011).

In legal research, there are several approaches that aim to obtain information from various aspects of the issue that is being sought answers (Ibrahim, 2008). In this connection, in writing this article using a statutory approach and a conceptual approach.

\section{Results and Discussion}

\subsection{Definition of Legis Ratio Determination of Minimum Percentage of Minority Share Ownership}

In order to answer the problems related to the Legis Ratio, the author will first explain what the definition of ratio legis is. In this study the authors conducted a discussion based on other legal materials, outside the documentation of the discussion of the Limited Company Law in the DPR RI, due to the constraints of limited documents from the DPR RI secretariat that the author could obtain in order to answer the Legis Ratio determining the minimum percentage of minority share ownership.

In the Black's Law Dictionary what is meant by ratio legis is the reason or purpose for making a law (Garner, 2004). Thus the definition of ratio legis from determining the minimum percentage of minority share ownership, is the legal reason or legal basis for the determination of the minimum percentage of minority shareholding, in Law Number 40 of 2007 concerning Limited Company.

From the discussion and analysis carried out in this study, in order to answer the problem formulation, the results of the discussion are expected to answer the background of legal reasons, the basis for certain legal considerations in determining the minimum percentage of minority share ownership is $10 \%$ as stated in Law Number 40 of 2007 concerning Limited Company.

\subsection{Limitation of Minority Share Ownership in Law Number 40 of 2007 concerning Limited Company.}

Based on Law Number 40 of 2007 concerning Limited Company, Article 79 paragraph (2), Article 97 paragraph (6), Article 114 (6), Article 138 paragraph (3), and Article 144, the contents of these articles contain the words that explicitly state "1/10 (one tenth) or more of the total shares with voting rights".

From the mention of the number $1 / 10$, it can be explained that the UUPT does not explicitly stipulate the percentage limit of Minority Share ownership is $10 \%$ (ten percent), but it can be understood that the percentage limit of Minority Share ownership in Law Number 40 of 2007 is 10\% (ten percent). Thus the limitation on the percentage of minority shareholding in Law Number 40 of 2007 concerning Limited Company is 10\% (ten percent).

\subsection{The existence of Minority Shareholders in Law Number 40 of 2007}

In terms of justice, minority shareholders only receive justice in the form of the main rights of shareholders, but do not have full rights according to the rights stated in Law Number 40 of 2007, in other words there is no justice and no legal protection for minority shareholders.

Thus the existence of minority shareholders in Law Number 40 of 2007 concerning Limited Company is only a complement to capital, in the sense that the minority shareholders' obligation to deposit capital must be fulfilled by minority shareholders, there are no exceptions for minority shareholders in to deposit or complete their obligations in terms of paid-up capital, but in terms of exercising their rights as stipulated in Law Number 40 of 2007, minority shareholders are not entitled to use all the articles in Law Number 40 of 2007, namely shareholders are not entitled to use Article 79 paragraph (2), Article 79 
paragraph (6), Article 80 paragraph (1), Article 97 paragraph (6), Article 114 (6), Article 138 paragraph (3), and Article 144 because there is a requirement for a minimum percentage limit of $10 \%$ share ownership.

\subsection{The essence of the GMS for Minority Shareholders in Law Number 40 of 2007}

After discussing the existence of minority shareholders in Law Number 40 of 2007, then it is necessary to discuss the essence of the GMS for minority shareholders. Based on Law number 40 of 2007 concerning Limited Company, it states that the General Meeting of Shareholders (GMS) is a company organ that has the authority not given to the Board of Directors or the Board of Commissioners within the limits specified in this Law and / or articles of association, as stipulated in Article 1 number 4 Law Number 40 of 2007. The GMS is one of the organs of a Limited Company regulated in Article 1 number 2 Law Number 40 of 2007 which states that the Company Organ is the General Meeting of Shareholders, Directors and Board of Commissioners.

The authority of the GMS is also regulated and reiterated in Article 75 paragraph (1) Law Number 40 of 2007 which reads: The GMS has authority that is not granted to the Board of Directors or the Board of Commissioners within the limits stipulated in this Law and / or the articles of association. So in general, what powers are not given to the Board of Directors and / or the Board of Commissioners, becomes the authority of the GMS. Therefore, it can be said that the GMS is the highest organ of the company (Harahap, 2013).

Whereas in every vote or voting that occurs at the GMS, in relation to the principle of one share one vote, the GMS forum is the highest forum of a Limited Company that can be accessed by all shareholders, including minority shareholders. Thus, although it can be estimated that minority shareholders will always lose votes if voting is carried out in the voting at the GMS forum, because it is clear that although it is likely that minority shareholders will lose their votes, minority shareholders can participate in the GMS or EGM and participating in voting are very important matters.

Thus the essence of the GMS (General Meeting of Shareholders) for minority shareholders is the only organ of a Limited Company that can be accessed, followed by minority shareholders, by attending the GMS as the highest organ of a Limited Company, so that the GMS is a very important forum. and useful for minority shareholders in exercising control or control over the management of a Limited Company carried out by the Board of Directors, as well as for knowing the activities and conditions of the Limited Company.

\subsection{Unenforceable Rights of Minority Shareholders and Constraints}

In Law Number 40 of 2007 concerning Limited Company, there are rights for shareholders, but based on Law Number 40 of 2007, not all rights for these shareholders can be enjoyed by minority shareholders, because of the limitations on share ownership stipulated in Law Number 40 of 2007.

For minority shareholders (shareholders with share ownership percentage below 10\%) in order to fulfill the requirements of Article 79 paragraph (2), Article 97 paragraph (6), Article 114 (6), Article 138 paragraph (3), and Article 144 Law Number 40 of 2007 which explicitly states "1/10 (one tenth) or more of the total shares with voting rights, which is the minimum percentage limit of $10 \%$ share ownership, then the only way or effort that can be made by shareholders minority is trying to cooperate or collaborate with other shareholders to be invited to ally and join forces in order to comply with the minimum limit of $10 \%$ share ownership. It should be noted that finding other shareholders who agree or have the same interests, to partner with or join, is very difficult, or rarely achievable in the business world.

Thus the obstacle for minority shareholders in exercising their rights as shareholders is that there are obstacles in meeting the requirements or the minimum percentage limit of $10 \%$ share ownership. The constraint on the minimum percentage of $10 \%$ share ownership is an obstacle that is difficult to overcome or difficult for minority shareholders to face. Thus, the minimum percentage limit of $10 \%$ share ownership in Law Number 40 of 2007 has become an obstacle for minority shareholders 
(shareholders with a share ownership percentage of less than 10\%) to exercise their rights as shareholders.

\subsection{Relationship between Minority Shareholders and Request for GMS and Filing of Lawsuit}

As it is known, minority shareholders have limitations in submitting a request for a GMS because there is a minimum percentage limit of $10 \%$ minority share ownership. Given these limitations, the only way for minority shareholders to protect their rights as the injured shareholder is by filing a lawsuit as regulated in Article 61 of Law Number 40 of 2007 . On the other hand, it turns out that filing a civil lawsuit to the local District Court based on Article 61 of Law Number 40 of 2007 requires a long time and a large amount of money.

Thus, because minority shareholders have limitations in fulfilling the minimum percentage limit of $10 \%$ share ownership in submitting a request for a GMS, minority shareholders have only a option to fight for their interests or rights, namely by filing a civil law lawsuit to the local district court based on Article 61 of the Company Law. Filing a civil lawsuit to the district court based on Article 61 of Law Number 40 of 2007 turns out to take a long time and costs a lot, so the existence of Article 61 of Law Number 40 of 2007 has not provided justice and legal protection for the rights of minority shareholders.

In fact, in a Limited Liability Company, there is often unfair treatment from the majority shareholder and the company's management towards minority shareholders. There are three important factors that cause this unfair treatment, namely:

First, the lack of provisions in laws and regulations that protect the rights of minority shareholders. In fact, even though these provisions exist, they are still not sufficient. This is evident from the frequency of minority shareholders whose interests have been harmed by majority shareholders who have bad intentions in implementing Law Number 40 of 2007 . In addition, the existence of the authority granted by Law Number 40 of 2007 to the organ of the GMS to determine company policies, explicitly does not regulate the obligation of active participation for minority shareholders to submit their opinions, as a result the majority shareholder is so dominant and can easily ignore the rights of minority shareholders.

Second, attitudes and behavior of majority shareholders, Directors or Commissioners that have moral hazard characters. This attitude factor, in the end, can cause losses to the Limited Company.

Third, the weak position of minority shareholders due to lack of capital, knowledge, skills and abilities to manage Limited Companies, so that minority shareholders are powerless in facing the attitudes and behavior of majority shareholders who have bad faith (Wilamarta, 2002).

\subsection{The Presence of the State in the Form of Economic Arrangements as stipulated in Law Number 40 of 2007}

That the state needs to be present in the regulation in the economic field in order to achieve justice for the community and in a smaller scope, namely the presence of the state in Law Number 40 of 2007 concerning Limited Company. The following is a further discussion on the presence of the state with legal authority owned by the state. To achieve justice for society in general and especially for minority shareholders, to carry out activities in the economic sector cannot be separated from the existence of a governing authority.

The British economist, Adam Smith, said that the only legitimate interest that should be pursued in the business world is the interest of making maximum profit. When business people are given the opportunity and discretion to pursue the interests of seeking profit, it is precisely with this that the community will get the maximum benefit from the business world. However, a company is not allowed to act freely in pursuit of maximum profit, because everything must be done within the corridors or boundaries of the game rules that have been mutually agreed upon, namely the existence of laws and regulations. In other words, it is necessary to have the presence of the State in the form of a law, so that the law is necessary and must provide a guiding rail and protection for a company in carrying out its activities in order to get maximum profit (Nadapdap, 2018). About the need for the presence of the State in regulating the economy was also put forward by a well-known economist named John Maynard 
Keyness (1833-1946) who emphasized the importance of state intervention to build a just economic system (Ujan, 2017).

In terms of justice, for the sake of social life, every individual or citizen, or certain group, will always try to fight for each individual to get a decent life, as the hope of every Indonesian citizen is to live in prosperity, therefore the state must be present with The goal of providing justice and fairness is something that the community at large wants to achieve, and especially for minority shareholders in a Limited Company.

To achieve justice for minority shareholders, there is a principle or doctrine, namely the Fiduciary Duty doctrine. The doctrine of fiduciary duty is one of the most important areas in corporate law, which originates and has its roots in Roman law, but has been largely developed by the Anglo Saxon legal system, it has infiltrated various fields of law, including corporate law by introducing it as a duty. fiduciary of the board of directors (Fuady, 2014).

If it is related to the existence of a Limited Company which is a form of Legal Entity used by the public in economic activities, then the legal authority to regulate economic activities related to the existence of a Limited Company is the State in the form of legal rules regulating the existence of a Limited Company, namely Law Number 40 of 2007 concerning Limited Company. Thus, with the presence of Law Number 40 of 2007 concerning Limited Company, it is a form of the state's presence to regulate the Limited Company in order to provide justice and legal protection for all shareholders, especially for minority shareholders, for all stakeholders, and for society in general.

From the constitution of the Indonesia, namely UUD 1945, it can be seen that the existing economic system in Indonesia. Article 33 paragraph (1) UUD 1945 states that "... the economy is structured as a joint effort". In the economic system, the most productive and efficient institution to try together is the market. Therefore, the national economic system also applies a market based on "justice", not a market mechanism based on free competition (Tjakrawerdaja, 2019). From the contents of this constitution, then the State is present in the form of a law that regulates the Indonesian economy. One of the laws that apply in the economic sector is Law Number 40 of 2007 concerning Limited Company.

Thus, the State of the Republic of Indonesia must be present in the community in the form of economic regulations as stipulated in Law Number 40 of 2007, to provide justice and protect the rights of all shareholders of a Limited Company, not limited to only the majority shareholder, but also to minority shareholders. The existence of Law Number 40 of 2007 concerning Limited Company is a form of the state's presence in making arrangements in the economic sector which is able to provide justice for the public in general, and in particular for all shareholders.

\subsection{The Relation of Minimum Percentage of $10 \%$ Minority Share Ownership with Decision Making for Companies and Convenience for Investors}

To make it easier for investors so that investors are interested in investing in the company, it is necessary to limit the minimum percentage of minority share ownership. With the limitation for minority shareholders who can submit, request and / or file claims according to their rights as minority shareholders, it is hoped that the performance of Limited Companies will be better.

The Board of Directors as the party responsible for managing or managing the Limited Company will be able to carry out its duties and authorities properly if the Board of Directors has the support of all shareholders, so that starting from the beginning when the Board of Directors presents the annual work plan, it is expected that all shareholders support the work plan prepared by Directors, even if there is criticism from shareholders, it is hoped that the criticism will be constructive criticism. It is different if the Board of Directors does not receive support from shareholders, it is possible that the decision made by the Board of Directors is not supported by the shareholders, even shareholders who do not support the decision making by the Board of Directors (which can also be interpreted as the Company's decision) can easily make a problem the decision of the Board of Directors, or in other words discrediting the Board of Directors through the GMS forum, by means of the shareholder requesting 
a GMS with the meeting agenda discussing actions, policies or decisions of the Company relating to the management of the company, which are deemed inappropriate and detrimental to the Company. For example, the disturbance to the performance of the Board of Directors that occurs is when certain shareholders always question or discredit any decisions from the Board of Directors which are actually based on good faith on the basis of the business judgment rule, the disturbance to the Board of Directors can arise by means of the particular shareholder requesting implementation GMS.

If it turns out that the GMS is often requested by the shareholders, then of course the performance of the Board of Directors will be disturbed, because the Board of Directors cannot carry out good management of the Limited Company, so that it will have a direct impact on the Company's performance to deteriorate, because the Board of Directors is busy preparing for the holding of the GMS.

The implementation of the GMS will clearly incur a certain amount of time, money and energy from the Board of Directors, therefore if the GMS agenda is not constructive but instead there is a practical political content to overthrow the Board of Directors, then of course the GMS is often held but with unconstructive purposes all shareholders without a percentage limit can request a GMS, this will disturb the performance of the Board of Directors and will also have an adverse impact on the Company.

If each minority shareholder without a minimum percentage limit can freely request a GMS, file a derivative suit, submit a request for examination to the District court and submit a proposal for dissolution in accordance with their rights as a shareholder without a minimum share ownership limit, then the duties of the Board of Directors will only be busy with the implementation. GMS, or busy carrying out activities aimed at fulfilling the demands / requests of minority shareholders, spend a lot of time and money to face lawsuits in court in the form of derivative lawsuits, requests for examination at the District Court, and are busy facing proposals for the dissolution of the Company to the GMS, so that The main task of the Board of Directors to manage Limited Companies has been neglected.

Thus the determination of a minimum share ownership percentage of $10 \%$ is to create conducive conditions for the Company and facilitate decision making of limited company by the Board of Directors, in order for the Board of Directors to carry out efficient and effective management or management of Limited Company to achieve good corporate performance, because only shareholders with a minimum shareholding percentage of $10 \%$ who has the right to request a GMS, has the right to file a lawsuit in the form of a derivative lawsuit, the right to submit an audit request to the district court and submit a dissolution proposal, and in order to provide convenience to investors, so that investors are interested in investing in the company.

\subsection{Background number assignment $10 \%$}

The following is a discussion of why the number $10 \%$ is set, and not another number as the minimum percentage limit for minority shareholding.

In the era of 2007, Indonesia had a Gross Domestic Product (GDP) per capita of 1.860, 00 USD for the same year in the ASEAN region for Singapore's GDP per capita was 39.432,94 USD and Malaysia's GDP per capita was 7.243,46 USD. From the GDP per capita figures of Indonesia, it is possible to know the real condition of the Indonesian economy at a macro level, so that all policies and actions of the Indonesian Government must take into account the Indonesian economic conditions, in this case including the condition of the Indonesian economy during the 2007 era into consideration in determining $10 \%$ as the minimum percentage of minority share ownership in Law Number 40 of 2007.

Whereas the $10 \%$ number is far below the $50 \%$ number, where the $50 \%$ number will lead to or show the majority number, thus it can be seen that the $10 \%$ percentage number is not the majority number. With the determination of the number $10 \%$, it can show that the number $10 \%$ when compared to the total shares of $100 \%$ ( a part as a whole), then the number $10 \%$ is a minority. 
Shareholders with an ownership percentage of $10 \%$ or below $10 \%$ know that the share ownership portion of their shares is far below the majority, or relatively far compared to the majority shareholder who owns $50 \%$ shares, so that shareholders with ownership of $10 \%$ or below $10 \%$ can accept and consider it a natural thing if he as a shareholder is positioned as a minority shareholder.

That regardless of the amount of rupiah deposited by the shareholders as paid-up capital in a limited liability company, if it is related to the value, it is certain that the amount of rupiah will have a value, so that from the paid-up capital that has been paid by a shareholder, it will be associated whether the paid-up capital of the shareholder high or low value, the higher the value, the shareholder can be called the majority shareholder, and vice versa, the lower the value, the shareholder can be called a minority shareholder.

Thus, the background for determining the number $10 \%$ as the minimum percentage limit for minority share ownership in Law Number 40 of 2007 is a variety of backgrounds. The following is the background in question:

a. The condition of the Indonesian economy when Law Number 40 of 2007 was drafted also influenced the determination of the minimum percentage of minority shareholding, so that in Indonesia the figure was set at $10 \%$.

b. Whereas the $10 \%$ percentage is not the majority.

c. Whereas $10 \%$ is a fair percentage number for shareholders who have paid-up capital to be considered as minority shareholders.

d. Whereas the determination of the number $10 \%$ is carried out by considering the value of the rupiah that has been deposited by the shareholders as paid up capital.

\subsection{Analysis Results to Answer Ratio Legis Minimum Percentage of Minority Share Ownership 10\%}

From the descriptions and discussion above, a more detailed discussion can be obtained so that this discussion can answer:

(i) legal background reasons, legal grounds for determining the minimum percentage of minority share ownership; and

(ii) legal background, legal considerations. The percentage of Minority Shares is determined to be $10 \%$.

a. The following are important points to answer the background of legal reasons, the basis of legal considerations for determining the minimum percentage of minority shareholding, namely as follows:

(i) The presence of the state in the form of regulation in the economic sector, namely through the issuance of Law Number 40 of 2007 concerning Limited Company which aims to provide justice and legal protection for all shareholders, including for minority shareholders, as well as for all stakeholders. Regulation by the State in the field of law and in the economic sector in the form of the issuance of Law Number 40 of 2007 concerning Limited Company, in which it also regulates or stipulates more detailed matters, namely determining the limit of $10 \%$ minority shareholding.

(ii) Facilitate decision making for Limited Company in the context of the Board of Directors to carry out efficient and effective management or management of Limited Company to achieve good company performance, because only shareholders with a share ownership percentage of at least $10 \%$ are entitled to request a GMS, submit an Audit Request to the district court and submit proposed dissolution. With the determination of the minimum percentage of share ownership is $10 \%$, the determination of the minimum percentage of share ownership will increase efficiency and 
effectiveness in the Company's decision-making process.

If every shareholder without a minimum percentage limit can freely request a GMS, submit a request for examination to the district court and submit a proposal for dissolution in accordance with their rights as a shareholder without a minimum share ownership limit, then the duties of the Board of Directors will only be busy holding the GMS and busy carrying out activities which aims to meet the demands and / or demands of the shareholders, so that the main task of the Board of Directors to manage the Limited Company is neglected.

(iii) Provides convenience for investors who have invested in large amounts. Investors who invest in large amounts can also be called the majority shareholder. Every investor who has invested a large amount in a Limited Company will expect that his investment (Paid-in Capital) can be economically rapidly developed to generate profits, for that the majority shareholder as an investor who has invested in Paid-up Capital in a Limited Company, will spirit of investing if the rules of the game in the management of a Limited Company are made simple and minimize the risk of disruption to decision making by the Board of Directors in the context of managing the company, due to the many requests and / or demands of minority shareholders whose investment value or paid-up capital is relatively small.

(iv) So that minority shareholders with share ownership below $10 \%$ do not make efforts to claim their rights which could interfere with the performance of Limited Company management or Limited Company management. With the consideration that if there are several minority shareholders with share ownership below 10\%, each minority shareholder requests their rights by filing a lawsuit, for example: filing a derivative lawsuit by suing the Board of Directors or Commissioners, then the derivative lawsuit from some minority shareholders, will interfere with the performance of the company's management, because there will be many lawsuits that must be faced by the management.

b. The following are important points to answer the background of legal reasons, the legal basis for determining the percentage of minority shares is determined to be $10 \%$.

(i) The condition of the Indonesian economy when Law Number 40 of 2007 was made also influenced the determination of the minimum percentage of minority shareholding, so that in Indonesia the number was determined to be $10 \%$. If the condition of Indonesia's economy in the future is more advanced, including more and more investors investing in establishing Limited Company and the greater the capital invested in Limited Company, the $10 \%$ number will be reduced, become smaller, due to the advancement of the economy a country.

(ii) That the $10 \%$ percentage is not the majority number, because the $10 \%$ number is far below the $50 \%$ number, where the 50\% number will lead to or show the majority number. Thus by determining the number $10 \%$ can show that $10 \%$ when compared to the total shares of $100 \%$, then the number $10 \%$ is a minority. It is different if the $48 \%$ or $49 \%$ number is determined as the minimum percentage of minority shareholding, then the determination of the $48 \%$ or $49 \%$ number will cause debate, because the distance between $48 \%$ or $49 \%$ to $50 \%$ (which is considered the majority) is very near.

(iii) Whereas $10 \%$ is a reasonable percentage number for shareholders who have paid-up capital to be considered as minority shareholders. Shareholders with an ownership percentage of $10 \%$ or less than $10 \%$ know that the share ownership portion of their shares is far below the majority, or relatively far compared to the majority shareholder who owns $50 \%$ shares, so that shareholders with ownership of $10 \%$ or below $10 \%$ can accept and consider it a natural thing if he as a shareholder is positioned as a minority.

(iv) Whereas the determination of the number $10 \%$ is carried out by considering the value of the rupiah that has been deposited by the shareholders as paid up capital. With the paid-in capital that has been invested by the shareholders, the 
value of the amount of rupiah to acquire the $10 \%$ share ownership will have a value to be considered a minority.

\section{Conclusion}

Based on the analysis above, it can be concluded that; From the descriptions and discussion in this research, which is then carried out the analysis can be seen the background of legal reasons, the basis for legal considerations in determining the minimum percentage of minority share ownership is $10 \%$ as stated in Law Number 40 of 2007 . Thus, from the discussion and analysis, the following conclusions can be obtained.

The Ratio Legis for determining the minimum percentage of minority shareholding is $10 \%$ in Law Number 40 of 2007 concerning Limited Company, which are the presence of the state in the form of regulation in the economic sector, namely through the issuance of Law Number 40 of 2007 concerning Limited Company which aims to provide justice and legal protection for all shareholders. With the determination of the minimum percentage of $10 \%$ minority share ownership in Law Number 40 of 2007, it will facilitate decision making for Limited Company in the context of the Board of Directors to carry out efficient and effective management or management of Limited Company to achieve good corporate performance, without much interference from minority shareholders (shares below 10\%) demanding their rights which risk causing disruption to the performance of the Limited Company management or Limited Company management. In the end, determining the minimum percentage of $10 \%$ minority shareholding will make it easier for investors who have invested large amounts of capital in the formation of a Limited Company.

In the case of determining the $10 \%$ percentage, the determination of the $10 \%$ percentage figure is based on legal considerations:

a. Taking into account the conditions of the Indonesian economy when Law Number 40 of 2007 was drafted. With the condition of the Indonesian economy in the future increasingly advanced, including the more investors who invest in establishing Limited Company and the greater the capital invested in Limited Company, the $10 \%$ number will be reduced, become smaller;

b. that the $10 \%$ percentage is not the majority number, because the $10 \%$ number is far below the $50 \%$ number, which is the $50 \%$ number will lead to or show the majority number. By determining the number $10 \%$ can show that $10 \%$ when compared to the total shares of $100 \%$, then the number $10 \%$ is a minority;

c. The $10 \%$ number is a reasonable percentage number for shareholders who have paid-up capital to be considered as minority shareholders. Shareholders with an ownership percentage of $10 \%$ or below $10 \%$ know that the share ownership portion of their shares is far below the majority, or relatively far compared to the majority shareholder who owns $50 \%$ shares, so that shareholders with ownership of $10 \%$ or below $10 \%$ can accept and consider it normal if he as a shareholder is positioned as a minority;

d. Taking into account the value of the rupiah that has been deposited by the shareholders as paid-in capital, the value of the amount of rupiah to obtain the $10 \%$ share ownership will have a value to be considered a minority.

As is known in Law Number 40 of 2007 concerning Limited Company, the determination of the minimum percentage of minority shareholding is set at $10 \%$ and applies to all Limited Company, without considering certain classifications of Limited Company, including there is no difference from Limited Company with small capital to Limited Company with large capital. Thus, the limitation on the percentage of $10 \%$ minority shareholding applies rigidly or rigidly without considering other matters. By rigidly determining the minimum percentage of minority shareholding at $10 \%$, this will create a condition of injustice for minority shareholders.

Thus, as a recommendation in order to improve future laws, it is necessary to formulate additional rights for minority shareholders, namely the following rights: Minority shareholders are entitled to 1 (one) seat of Commissioner in a Limited 
Research, Society and Development, v. 10, n. 1, e41310111899, 2021

(CC BY 4.0) | ISSN 2525-3409 | DOI: http://dx.doi.org/10.33448/rsd-v10i1.11899

Company. Small, Medium or Large Limited Company; minority shareholders within a certain period have the right to make on the spot visits, to enter and review the operational locations of the Limited Company; minority shareholders have the right for a certain period to hold hearings or hearings with the Board of Directors and Board of Commissioners; minority shareholders who own shares in Medium Limited Company and Large Limited Company have the right to ask the Board of Commissioners and Directors to appoint a Public Accounting Firm (KAP) to conduct an audit; and has the right to request the Board of Commissioners and Directors to enforce restrictions on the provision of audit services by KAP; and the existence of articles that regulate special requirements for the management of a Limited Company which is engaged in certain types of business that are vulnerable to business risks to be required to undergo a fit and proper test or to have certain certificates.

With additional rights for minority shareholders, minority shareholders will get justice and legal protection, so that even though their votes are small they still get justice and legal protection, because the interests of minority shareholders are more secure, not always harmed by the Board of Directors or the majority shareholder who has full control over the management of the Limited Company.

\section{References}

Fuady, M. (2014). Doktrin-Doktrin Modern dalam Corporate Law dan Eksistensinya dalam Hukum Indonesia: Citra Aditya Bakti.

Garner, B. (2004). Black's Law Dictionary: Thomson West.

Harahap, Y. (2013). Hukum Perseroan Terbatas: Sinar Grafika.

Ibrahim, J. (2008). Teori dan Metodologi Penelitian Hukum Normatif: Bayumedia Publishing.

Kadir, T. (2017). Gugatan Derivatif, Perlindungan Hukum Pemegang Saham Minoritas: Sinar Grafika.

"Indonesia. (2007). Law Number 40 of 2007 concerning Limited Company. https://www.ojk.go.id/sustainable-finance/id/peraturan/undangundang/Documents/5.\%20UU-40-2007\%20PERSEROAN\%20TERBATAS.pdf

“Indonesia. (2007). Laws Number 1 of 1995 Concerning Limited Company. https://www.bphn.go.id/data/documents/95uu001.pdf

Marzuki, P. (2011). Penelitian Hukum: Kencana.

Nadapdap, B. (2018). Hukum Perseroan Terbatas, Berdasarkan Undang-Undang No. 40 Tahun 2007: Jala Permata Aksara.

Nasution, B. (2008). Metode Penelitian Ilmu Hukum: Mandar Maju.

Prasetyo, T., \& Barkatullah, A. H. (2014). Filsafat, Teori, \& Ilmu Hukum: Rajagrafindo Persada.

Tanya, B., Simanjuntak, Y., \& Hage, M. (2013). Teori Hukum Strategi Tertib Manusia Lintas Ruang dan Generasi: Gentang Publishing.

Tjakrawerdaja, S., Soedarno, S., Lenggono, P., Purwandaya, B., Karim, M., \& Agusalim, L. (2019). Sistem Ekonomi Pancasila: Rajawali Pers.

Ujan, A. (2017). Sistem Ekonomi dan Keadilan: Sebuah Telaah Etis: Kanisius.

Wilamarta, M. (2002). Hak Pemegang Saham Minoritas Dalam Rangka Good Corporate Governance: Program Pascasarjana Fakultas Hukum Universitas Indonesia. 